\title{
Haemoproteus minutus is highly virulent for Australasian and South American parrots
}

\author{
Luis Ortiz-Catedral', Dianne Brunton ${ }^{1}$, Mark F. Stidworthy' ${ }^{2}$, Hany M. Elsheikha ${ }^{3}$, Tom Pennycott ${ }^{4}$, \\ Christoph Schulze ${ }^{5}$, Michael Braun ${ }^{6}$, Michael Wink ${ }^{6}$, Helga Gerlach7, Helene Pendl ${ }^{8}$, Achim D. Gruber ${ }^{9}$, \\ John Ewen ${ }^{10}$, Javier Pérez-Tris ${ }^{11}$, Gediminas Valkiūnas ${ }^{12}$ and Philipp Olias ${ }^{13^{*}}$ (D)
}

\begin{abstract}
Background: Haemoproteus and Plasmodium species are widespread avian blood parasites. Several Plasmodium species are known for their high virulence and have caused significant declines in naïve bird populations. The impact of closely related Haemoproteus parasites is largely unknown. Recently we reported a lethal disease in two parrot aviaries caused by Haemoproteus parasites.

Results: Here we show that the causative pathogen Haemoproteus minutus is responsible for further 17 lethal outbreaks in parrot aviaries in Denmark, Germany and Great Britain. All affected parrots are endemic to Australasia and South America. We sequenced the cytochrome $b$ gene from megalomeront-infected muscle tissue of 21 parrots and identified the two lineages TUPHI01 and TURDUS2 as causative agents, commonly naturally infecting the common blackbird (Turdus merula) and the song thrush (Turdus philomelos), respectively, in the Palaearctic. No intraerythrocytic parasite stages were found in any of the parrots. We failed to detect $\mathrm{H}$. minutus in invasive Indian ring-necked parakeets (Psittacula krameri) in Germany. Together this suggests that abortive infections with two virulent lineages of H. minutus are lethal for naïve parrot species from Australasia and South America. We asked whether we could detect H. minutus in New Zealand, where its Turdus hosts were introduced in the 1800s. We therefore tested invasive blackbirds and song thrushes, and the co-existing endemic red-fronted parakeet (Cyanoramphus novaezelandiae) population on three New Zealand islands. No Haemoproteus spp. DNA was detected in all blood samples, indicating absence of transmission.

Conclusions: The results of this study show that captive parrots in Europe are threatened by two lineages of an otherwise benign parasite of Turdus spp. Aviary collections of parrots should be protected from Culicoides spp. vectors in Europe. Animal trade and climate changes extending the current vector and parasite distribution have to be considered as potential risk factors for the introduction of the disease in naïve parrot populations.
\end{abstract}

Keywords: Haemoproteus, Plasmodium, Malaria, Haemosporida, Apicomplexa, Psittaciformes, Parrot, Conservation

\section{Background}

Generalist pathogens (i.e. capable of infecting a wide range of hosts) can pose a serious threat for immunologically naïve animal host populations if they spread, e.g. by changing climate conditions, unintentional or deliberate introduction [1]. Emerging pathogens can have a devastating effect on the wildlife biodiversity as exemplified by the pandemic of the white nose syndrome fungus

\footnotetext{
* Correspondence: philipp.olias@vetsuisse.unibe.ch

${ }^{13}$ University of Bern, Institute of Animal Pathology, Länggassstrasse 122, 3063 Bern, Switzerland

Full list of author information is available at the end of the article
}

Pseudogymnoascus destructans in the USA responsible for severe bat population declines [2], and Batrachochytrium fungi causing widespread declines of amphibians worldwide $[3,4]$. In the past decades, environmental changes such as global temperature rises accelerated the main driver of epidemics in wildlife, the human-assisted introduction of infectious agents into naïve ecosystems [5]. Often, novel pathogens do not cause obvious disease in evolutionary adapted host species of their origin and only become pathogenic in naïve host species [6]. However, the factors determining the pathogenicity potential at the molecular level,

(C) The Author(s). 2019 Open Access This article is distributed under the terms of the Creative Commons Attribution 4.0 International License (http://creativecommons.org/licenses/by/4.0/), which permits unrestricted use, distribution, and reproduction in any medium, provided you give appropriate credit to the original author(s) and the source, provide a link to the Creative Commons license, and indicate if changes were made. The Creative Commons Public Domain Dedication waiver (http://creativecommons.org/publicdomain/zero/1.0/) applies to the data made available in this article, unless otherwise stated. 
rendering some host species more susceptible than others are most often not well understood.

Another textbook example of an invasive pathogen spread is that of avian malaria on the islands of Hawaii in the late 19th century that occurred after the two-step introduction of (i) the mosquito vector Culex quinquefasciatus followed by (ii) the malaria parasite Plasmodium relictum [7]. Since then the native bird population has been devastated below $1200 \mathrm{~m}$ of elevation where the sole vector of $P$. relictum is most active [8]. Most notable are the major extinctions of the endemic bird population of Hawaiian honeycreepers (Fringillidae, subfamily Carduelinae) $[7,9]$. Plasmodium relictum is the most successful malaria parasite worldwide, and is reported from over 300 avian species belonging to 11 orders [10]. Studies on experimentally infected birds found the $P$. relictum lineage GRW4 and the related species $P$. elongatum to be highly virulent for naïve hosts $[11,12]$. In novel hosts these parasites cause a marked blood pathology including anemia and hemolysis caused by intraerythrocytic parasite stages. However, the tissue pathology caused by their exo-erythrocytic stages is less well understood [13, 14]. Avian malaria parasites of the genus Plasmodium are closely related to haemosporidian parasites of the genus Haemoproteus, which are also infecting erythrocytes among other cells of birds. We recently reported outbreaks of an emerging fatal disease in captive parrots (Psittaciformes) in Germany and Switzerland caused by Haemoproteus parasites [15]. Parasites of this genus are widespread and usually considered to be relatively benign in native songbirds [16]. Other than for Plasmodium spp., the negative impact of Haemoproteus spp. on naïve bird populations and its pathogenicity potential is less well studied [17]. However, recent reports suggest that Haemoproteus parasites are frequently causing fatalities in naïve bird species $[14,18]$.

In the present study, we genetically characterized the lineages of Haemoproteus species responsible for fatal disease outbreaks in captive parrots throughout Europe and recorded the phylogenetic range of susceptible parrot species. Exo-erythrocytic parasite stages and the associated host pathology are described in detail. Parrots (Psittaciformes) are now considered the most threatened bird order with $56 \%$ of all parrot species in decline [19], and 29\% (115 of 399) species classified as vulnerable to critically endangered according the 2018 IUCN Red List [20]. Habitat loss and bird trade can be considered as main contributing threats [19]. Less is known on the impact of infectious diseases to this ongoing decline in parrot populations. Identifying causes of mortality and potential risk factors for infectious disease outbreaks are critical for the successful conservation management of highly endangered parrot species. We therefore tested the distribution of Haemoproteus parasites in freeranging parrot populations and assessed the risk of a disease spread into vulnerable naïve parrot populations in New Zealand.

\section{Methods}

Outbreaks of a fatal disease in parrots associated with megalomeronts of an unknown parasite species have been documented throughout Europe for a century [21]. We collected tissue samples of lung, heart, gizzard, proventriculus, kidney, spleen, liver and intestine from captive parrots that died during 17 outbreaks in Denmark, England, Germany, and Scotland between 2002 and 2011 (Table 1) and re-evaluated previously reported cases from the literature (Table 2). Formalin-fixed and paraffin-embedded or fresh tissue from heart and gizzard muscle infected with megalomeronts were used for subsequent molecular analysis. For histopathological analysis, representative tissues fixed in $4 \%$ phosphate-buffered formalin and paraffin-embedded, routinely sectioned at $4 \mu \mathrm{m}$ and stained with haematoxylin and eosin (HE) were used. Imprints of unfixed tissue on glass slides were stained with Leishman stain.

Furthermore, blood samples were taken from 183 free-ranging ring-necked parakeets (Psittacula krameri) of Asian origin in Heidelberg, Germany, from 2009 to 2011. Two urban breeding colonies (SHA, $49^{\circ} 25^{\prime} 03.5^{\prime \prime} \mathrm{N}$, $8^{\circ} 41^{\prime} 02.9^{\prime \prime E} ; \quad$ ST-WH, $49^{\circ} 25^{\prime} 08.7^{\prime \prime N}, \quad 8^{\circ} 39^{\prime} 45.7^{\prime \prime E}$ ) were chosen. The birds (153 nestlings and 30 adults) were caught in their nest boxes during the breeding season between May and August. About $100 \mu \mathrm{l}$ of blood each bird was collected via brachial venipuncture and stored in EDTA buffer at $-20{ }^{\circ} \mathrm{C}$ until DNA isolation with the QIAmp DNA Mini Kit (Qiagen, Hilden, Germany) following the manufacturer's instructions.

Further blood samples were taken from two subspecies of free-ranging red-fronted parakeets (Cyanoramphus novaezelandiae; 138 adults and 59 nestlings) on three New Zealand islands in November 2009. Little Barrier Island $\left(36^{\circ} 11^{\prime} 24.2^{\prime \prime S}, 175^{\circ} 04^{\prime} 32.2^{\prime \prime} \mathrm{E} ; n=72\right.$ C. $n$. novaezelandiae sampled) and Tiritiri Matangi Island $\left(36^{\circ}\right.$ $36^{\prime} 01.0^{\prime \prime S}, 174^{\circ} 53^{\prime} 21.7^{\prime \prime} \mathrm{E} ; n=37$ C. $n$. novaezelandiae) are located in close proximity to the Northern main island in the Hauraki gulf, whereas Raoul Island $\left(29^{\circ}\right.$ $15^{\prime} 48.4^{\prime \prime} \mathrm{S}, 177^{\circ} 55^{\prime} 46.2^{\prime \prime} \mathrm{W}, n=88$ C. $n$. cyanurus) is located $\sim 995 \mathrm{~km}$ northeast off the coastline of the Northern main island. Little Barrier Island is an island of 3083 ha with the most pristine native avifauna remaining in New Zealand. Tiritiri Matangi Island is a smaller 220 ha-island on which most extant native avian species have been reintroduced over the past decades. Raoul Island (2938 ha) is a remote volcanic island on which breeding of C. $n$. cyanurus was recorded again in 2008 after an absence for 172 years. Most likely parakeets recolonised the island from the Herald Islets after goats, rats and 


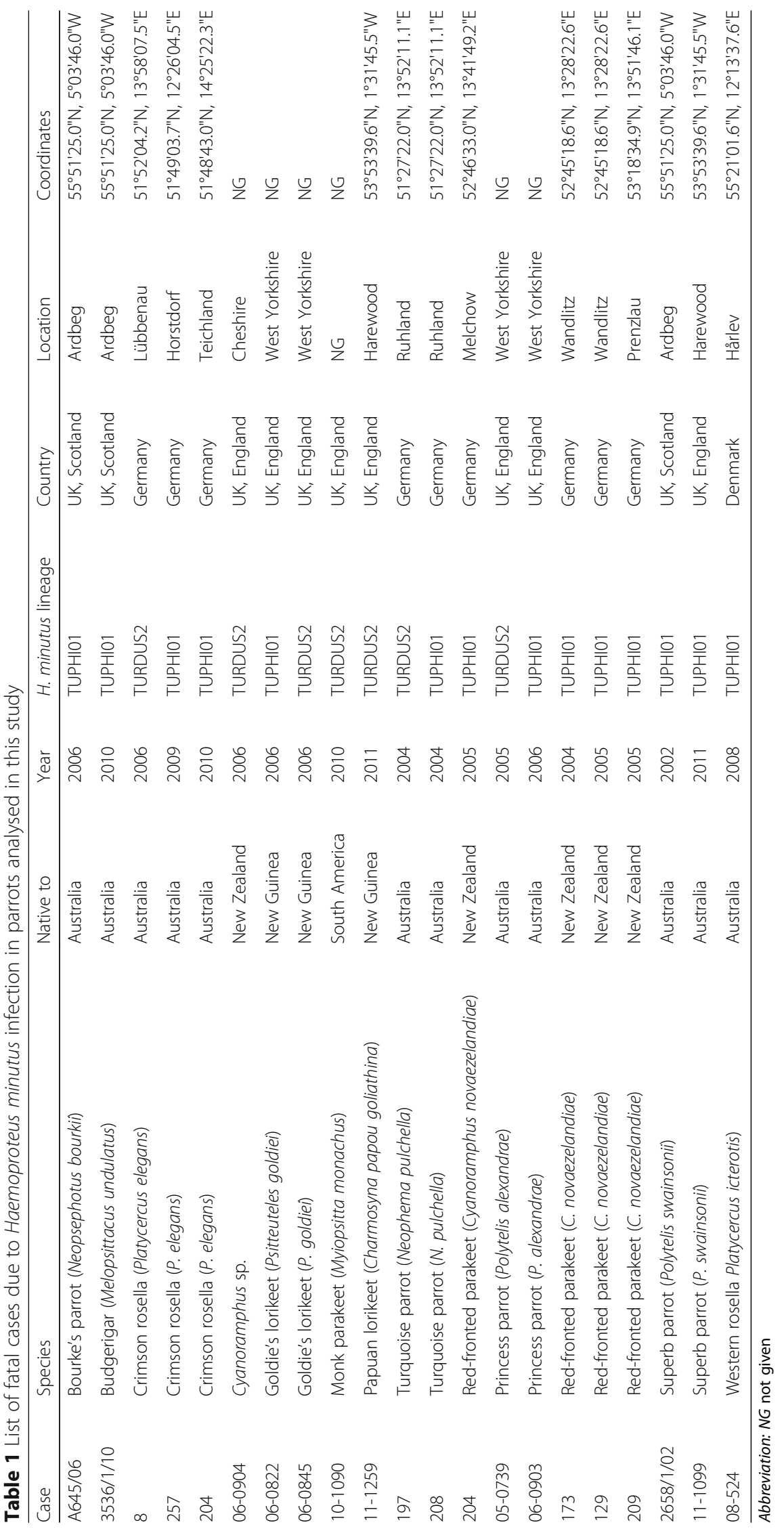


Table 2 List of parrots described in the literature to be affected by megalomeront structures in the heart and gizzard muscle other than identified in this study

\begin{tabular}{|c|c|c|c|c|c|}
\hline Species & Native to & Year & Country & Location & Reference \\
\hline Red-winged parrot (Aprosmictus erythropterus) & Australia & 1966 & Germany & Mosbach & [55] \\
\hline Scarlet-chested parrot (Neophema splendida) & Australia & 1979 & Germany & North Rhine-Westphalia & [56] \\
\hline Horned parakeet (Eunymphicus c. cornutus) & New Caledonia & NG & Switzerland & NG & [57] \\
\hline Northern rosella (Platycercus venustus) & Australia & 1972 & UK & NG & [58] \\
\hline Mulga parrot (Psephotus varius) & Australia & 1971 & UK & NG & [59] \\
\hline Pale-headed rosella (Platycercus adscitus) & Australia & 1971 & UK & NG & [59] \\
\hline Australian king parrot (Alisterus scapularis) & Australia & 1971 & UK & Cornwall & [60] \\
\hline Regent parrot (Polytelis anthopeplus) & Australia & 1971 & UK & Glos. & [60] \\
\hline Yellow-crowned parakeets (Cyanoramphus auriceps) & New Zealand & 2010 & Switzerland & $52^{\circ} 16^{\prime} \mathrm{N}, 13^{\circ} 39^{\prime} \mathrm{E}$ & [15] \\
\hline Barred parakeet (Bolborhynchus lineola) & $\begin{array}{l}\text { South America, } \\
\text { Middle America }\end{array}$ & 2010 & Germany & $47^{\circ} 25^{\prime} \mathrm{N}, 8^{\circ} 50^{\prime} \mathrm{E}$ & [15] \\
\hline
\end{tabular}

Abbreviation: NG not given

cats have been removed [22]. In all locations, adult parakeets were captured using mist-nets, whereas nestlings were taken from their nests. From each parakeet about $70 \mu \mathrm{l}$ of blood was collected via brachial venipuncture using a heparinised capillary tube and stored at $4{ }^{\circ} \mathrm{C}$ until DNA extraction two days later with the Extract-N-Amp Tissue Kit (Sigma-Aldrich, St. Louis, USA) following the manufacturer's instructions. Blood samples from common blackbirds (Turdus merula; $n=$ 44) and song thrushes (Turdus philomelos; $n=19$ ) were taken from birds caught in mist nets on Little Barrier Island and Tiritiri Matangi Island in 2009. Both bird species are invasive species of European origin, which have been introduced in the late 19th century and firmly established themselves throughout New Zealand including Raoul Island [23]. About $70 \mu \mathrm{l}$ of blood from each bird was collected via brachial venipuncture and stored in $100 \%$ ethanol until DNA extraction.

To detect the presence of haemosporidian DNA in muscle and blood samples, we used a nested polymerase chain reaction (PCR) amplification method described by Hellgren et al. [24]. This method amplifies a $479 \mathrm{bp}$ segment of the parasite's cytochrome $b$ (cytb) gene. All PCR reactions were carried out using the GoTaq Flexi DNA Polymerase (Promega, Madison, Wisconsin, USA) according to the manufacturer's instructions. The following PCR protocol was used for the amplification of parasite cytb: initial denaturation at $94{ }^{\circ} \mathrm{C}$ for $3 \mathrm{~min}$, followed by 20 cycles at $94{ }^{\circ} \mathrm{C}$ for $30 \mathrm{~s}, 50{ }^{\circ} \mathrm{C}$ for $30 \mathrm{~s}, 72$ ${ }^{\circ} \mathrm{C}$ for $45 \mathrm{~s}$, and a final extension step at $72{ }^{\circ} \mathrm{C}$ for 10 $\mathrm{min}$. For the nested reaction, the same PCR conditions were used with 35 cycles. Amplicons were resolved on a $2 \%$ agarose gel stained with ethidium bromide and photographed under UV light. The avian $c y t b$ gene was amplified as described [25] to control for the DNA quality of each blood sample. No template controls used to detect DNA contamination of the PCR reagents always tested negative. $C y t b$ amplification products were purified using the NucleoSpin Extract II system (Macherey-Nagel, Düren, Germany) and sequenced by a commercial DNA sequencing service (Seqlab $\mathrm{GmbH}$, Goettingen, Germany) using the same forward and reverse primers. Sequences were compared with all sequences listed in the GenBank and MalAvi (http:// mbio-serv2.mbioekol.lu.se/Malavi/blast.html) databases using the BLAST program (https://blast.ncbi.nlm.nih.gov). Published Haemoproteus cytb sequences were derived from MalAvi database and trimmed to $351 \mathrm{bp}$ and 479 bp length, respectively, for comparison by CLUSTALW implemented in MEGA6. Lineage codes and GenBank accession numbers are given below. SplitsTree v4.14 was used to calculate unrooted phylogenetic networks using the neighbour-net method.

\section{Results}

Large tissue cyst-like structures resembling Haemoproteus megalomeronts were detected in 21 parrots (Psittaciformes; Table 1). Megalomeronts were located in the heart and gizzard muscle and frequently associated with extensive haemorrhages (Fig. 1a-e). Occasionally, megalomeronts were also found in other organs such as the lung (not shown). Macroscopically, parasite-associated haemorrhages appeared randomly scattered throughout the muscle tissue (Fig. 1a, d). Parasite structures were visible only microscopically (Fig. 1b, c, e). No host immune cell reaction was observed against the parasite. Megalomeronts were very often disrupted, and the remnants of the parasites (syncytia containing a portion of the cytoplasm and one or several nuclei) were present mixed with erythrocytes (Fig. 1f). Notably, we failed to identify intraerythrocytic Haemoproteus stages (gametocytes) in all parrots by histopathology. Although 

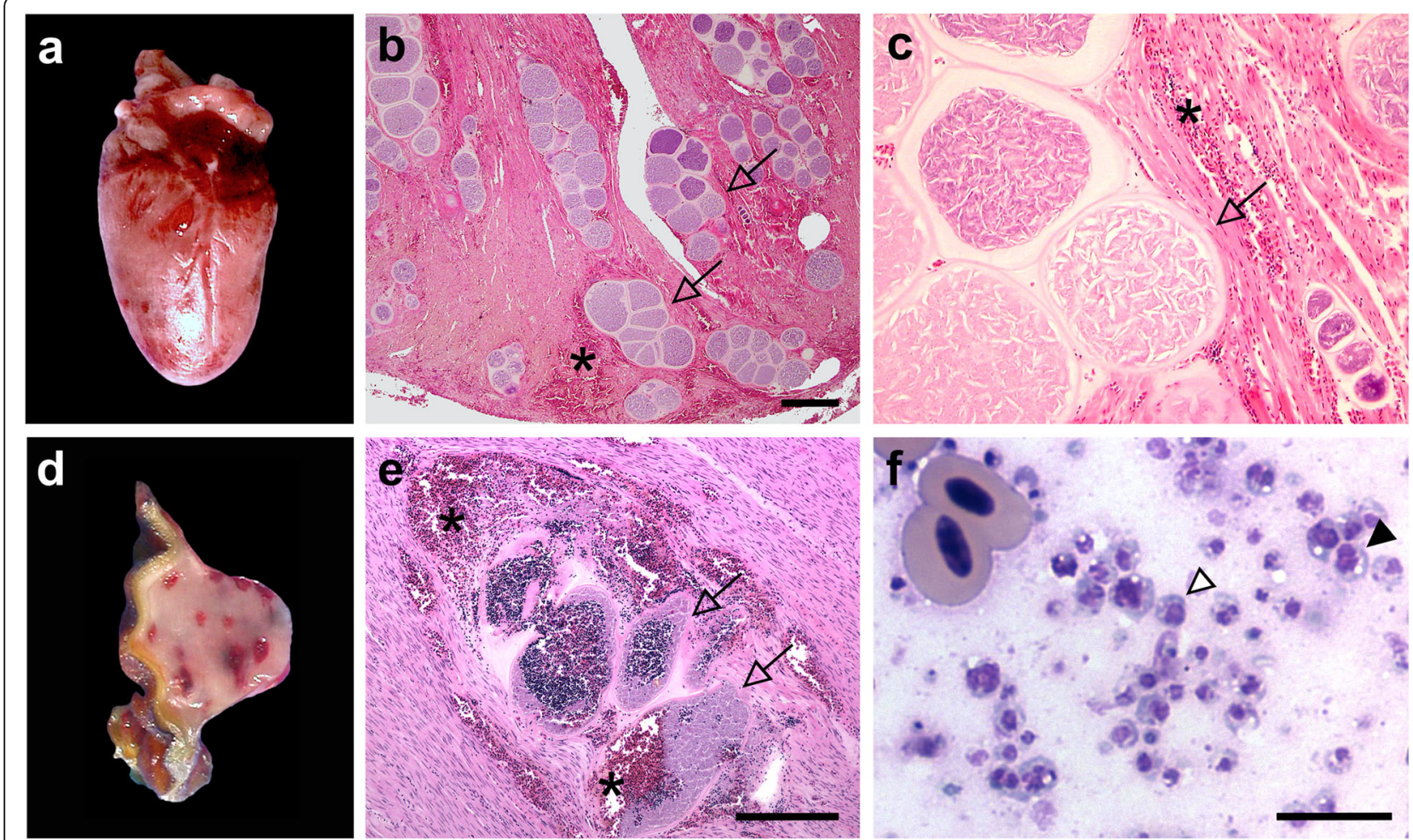

Fig. 1 The heart and gizzard muscle of a two months old superb parrot (Polytelis swainsonii) that succumbed to disease showed severe infection with megalomeronts (arrows) of Haemoproteus minutus. Multifocally extended haemorrhages are readily visible in the heart muscle (a) and gizzard muscle (d) associated with megalomeronts (e) in this parrot. Numerous roundish megalomeronts in different stages of growth (b), each covered with a prominent capsular-like wall (c, which is an insert of $\mathbf{b}$ ) disrupt the architecture of the heart muscle in a two weeks old Princess parrot (Polytelis alexandrae). Note the lack of a cellular host immune response towards the parasite. Imprint of gizzard muscle haemorrhages (f) associated with disrupted megalomeronts; e shows mixture of erythrocytes with syncytia originated from ruptured megalomeronts (f). Each syncytium possesses a portion of the cytoplasm and one (white arrowhead) or several nuclei (black arrowhead). During abortive development, the syncytia are readily washed out to the circulation and provide templates for PCR amplification in the blood even if intraerythrocytic stages (gametocytes) are absent. Asterisks, host tissue hemorrhage. Haematoxylin \& eosin (b, c and e) and Leishman (f) stain. Scale-bars: b and e 200 $\mu \mathrm{m} ; \mathbf{f} 10 \mu \mathrm{m}$

analysing erythrocytes in histopathological tissues sections is less reliable than in blood smears, this finding suggests that $H$. minutus does not complete its life-cycle and aborts the development of tissue stages in exotic parrot species.

Of the 21 individual parrots in which megalomeronts were detected in this study, 20 were native to Australasia and one to South America (Table 1). Phylogenetically, most species belonged to the tribes Platycercini and Psittaculini within the subfamily Psittacinae [26] (Table 1). Haemoproteus minutus lineages TURDUS2 and TUPHI01 were the only two parasite lineages detected by the comparison of amplified cytb gene sequences from infected muscle tissue samples with publicly available sequences (MalAvi database, http://mbio-serv2.mbioekol.lu.se/Malavi/blast.html; Table 1). A literature search for reports morphologically describing cysts-like structures resembling exo-erythrocytic megalomeront stages of $H$. minutus identified further eight parrots of the
Platycerini and Psittaculini tribes native to Australasia as potentially susceptible species (Table 2 ).

In a phylogenetic analysis, we compared TURDUS2 and TUPHI01 cytb gene sequences to psittacine Haemoproteus lineages (Fig. 2a, b). Although gametocytes of Haemoproteus spp. have been reported from more than 17 parrot species [27, 28] (Robert Adlard, International Reference Centre for Avian Haematozoa, personal communication), indicating complete life-cycles in these avian hosts, the molecular data on Haemoproteus lineages infecting parrots is scarce. We therefore added the cytb gene sequence (GenBank: KY783725) derived from a blood smear positive for mature Haemoproteus gametocytes of a South American green-winged macaw (Ara chloropterus) to our analysis [29]. For the phylogenetic network construction, we also included Haemoproteus lineages reported to infect thrushes and birds of closely related host families. The results show that TURDUS2 and TUPHI01 cluster with lineages infecting thrushes 




Fig. 2 Cytochrome $b$ sequences were incorporated into SplitsTree v4.14 to calculate unrooted phylogenetic networks using a neighbour-net method with 1000 bootstrap replicates. a Generalist TURDUS2 lineage of H. minutus is closely related to lineage COLL2 of H. pallidus which also has a wide host spectrum and geographical distribution, and is only distantly related to the lineage PSIKRA01 from the ring-necked parakeet $(P$. krameri). b H. minutus (lineages TURDUS2, TUPHIO1 and TUCHR01) cluster with lineages from thrushes (Turdidae; clade A) and are only distantly related to known parrot (Psittaciformes) lineages (clade B) from the brown-throated parakeet (Eupistaula pertinax; ARAPERO1) and green-winged macaw (Ara chloropterus; ARCHL01). Lineages reported from thrushes are shown in bold. Cytochrome $b$ sequences were derived from MalAvi and GenBank database and were trimmed for comparison to 351 (a) and 479 nucleotides (b), respectively. The following sequences were used: AFTRU06 (EU810734); ALPOL01 (AF465588); ARAPER01 (DQ241553); ARCHL01 (KY783725); ASPI01 (EF153652); CATUST02 (DQ490061); COLL2 (FJ355915); COLL3 (DQ067581); HIICT1 (JX026904); ICTAY02 (DQ241546); LULU1 (DQ060767); PARUS1 (AF254977); PFC1 (DQ63577); PHSIB1 (AF495565); PSIKRA01 (EF380207); ROBIN1 (AY393807); SFC1 (DQ060770); SIAMEX01 (AF465562); TERUF01 (EU819755); TUCAR01 (EF380166); TUCHR01 (EU676190); TUMIG06 (GQ141584); TUPHI01 (GU85191); TURDUS2 (DQ630013); WW2 (AY831755); ZOOLUN01 (AY714150)

(Turdidae; Clade A) and the generalist $H$. pallidus lineage COLL2, but are only distantly related to the parrot lineages ARAPER01, ARCHL01 and PSIKRA01 (Fig. 2).

Since our results suggest that parrot species from Australasia and to a lesser extent South America but not Asia and Africa can react highly sensitive to $H$. minutus infection and die from abortive megalomeront formation in the heart and other organs, we wondered whether wild parrot populations native to Asia and Africa are infected with $H$. minutus. We therefore chose to test blood samples of an invasive ring-necked parakeet (Psittacula krameri) population native to Asia, which habitat overlaps with an area where both virulent $H$. minutus strains are reportedly present [30]. We sampled 183 free-ranging parakeets (153 nestlings, 30 adults) caught in nest boxes from breeding colonies in Heidelberg, Germany. PCR for the avian cytb gene served as control for each sample. A comparison of the amplified cytb gene sequences with publicly available sequences in GenBank confirmed a most probable Asian origin of the parakeets [25]. Even though the ring-necked parrot in its native African-Asian range can become infected with Haemoproteus spp. [31], none of the 183 German birds tested positive for Haemoproteus spp. or Plasmodium spp.

Most exotic parrots affected by the disease in captivity in Europe are native to Australasia, with the exception of monk parakeets (Myiopsitta monachus) and barred parakeets (Bolborhynchus lineola) [15] (Table 2). We therefore decided to focus on Australasian species that share a distribution area with introduced Turdus thrushes and tested blood samples of native red-fronted parakeets (C. novaezelandiae) and introduced common blackbird and song thrush populations in New Zealand 
for the presence of $H$. minutus parasites. Red-fronted parakeets have been found to succumb to infection (Table 1) and can be considered at risk if $H$. minutus was introduced into the population. Blood samples were taken from 138 adult and 59 nestling parakeets from Little Barrier Island $(n=72)$, Tiritiri Matangi Island $(n=37)$ and Raoul Island $(n=88)$. Blood samples from common blackbirds $(n=44)$ and song thrushes $(n=19)$ were taken from birds caught in mist nets on Little Barrier Island and Tiritiri Matangi Island. Samples were processed as described above and $c y t b$ PCR amplicons were sequenced and compared to published sequences (MalAvi). We failed to detect Haemoproteus spp. infection in any of the parakeets or the thrushes. However, two Plasmodium lineages (GRW6, $n=3$; CYNOV1, $n=17$, GenBank: KY783726) were identified in the parakeets.

\section{Discussion}

A growing number of reports suggests that Haemoproteus blood parasites are more virulent in naïve birds than formerly believed. The pathology caused by these parasites in novel avian hosts appears to be mainly attributed to the damage of internal organs by exo-erythrocytic megalomeront stages [14, 32]. Our genetic findings on megalomeronts in exotic parrots in Europe revealed the two lineages TURDUS2 and TUPHI01 of the species $H$. minutus as highly virulent for birds of several distant parrot families. The common blackbird (Turdus merula) and the song thrush (Turdus philomelos) are the natural host species for both parasite lineages in the Palaearctic [30]. The extensive development of abortive $H$. minutus megalomeronts in the myocardium associated with haemorrhages prompted us to conclude that the deaths in these infected parrots were most likely caused by fatal heart failure due to disruption of cardiac function. Intra-erythrocytic parasite stages (gametocytes) and associated anaemia or internal organ damage due to infected erythrocytes building up in small blood vessels were not found. However, although a cellular immune response towards the parasite stages was absent, a strong and potentially fatal systemic immune response against parasite and host cell debris as well as toxic by-products cannot be excluded. It is also worth mentioning that deaths due to Haemoproteus infections have been reported in Asian and African parrots associated with intra-erythrocytic parasite stages [33-35], but pathological mechanisms underlying the mortality remained unclear. Experimental studies on $H$. minutus would be needed to better understand the disease mechanisms and the pathogenic potential of the two virulent parasite lineages TURDUS2 and TUPHI1 in birds. Sporogonic development of $H$. minutus isolated from the common blackbird in Culicoides impunctatus and Culicoides nubeculosus has recently been successfully achieved [17, 36]. This work opened new opportunities to study the host-parasite interaction of $\mathrm{H}$. minutus in the context of natural and aberrant host species on the molecular level.

Naïve parrot populations can be considered at risk, if virulent $H$. minutus lineages get introduced and established in a habitat that overlaps with an invasive thrush population where susceptible Culicoides vectors are available. Of the parrot species that we found to be susceptible to Haemoproteus spp. in this study, 95\% (18/ 19) are endemic to Australasia and one species to South America. Australasia and South America harbour the highest parrot diversity of extant species and the highest density of threatened bird species [37]. This great diversity of parrots in tropical and subtropical ecosystems of the southern hemisphere is markedly understudied in terms of their parasite diversity and only few parasites and their lineages have been described so far [29]. In addition to this study and a recent case report [15], the $H$. minutus lineage TUPHI01 has so far only been detected in wild thrushes (Turdidae) in Europe and eastern Russia. In contrast, the lineage TURDUS2 can be considered a generalist (multi-host) lineage, which was found in nine avian families distributed throughout the Holarctic (MalAvi). However, it remains unclear if the parasite completes its life-cycle in all of these birds since previous studies have shown that DNA from remnants of exo-erythrocytic stages of Haemoproteus species can be detected by PCR in the blood of infected birds [14, 15, 38]. Thrushes endemic to the Holarctic are considered adapted type-hosts of $H$. minutus, in which the parasite does not cause overt disease [17, 29]. Generalist blood-borne parasites that are able to infect multiple host species have been shown to be efficient colonisers of naïve avifaunas [39]. In Europe, the biting midge Culicoides impunctatus transmits $H$. minutus [17], but at least five other Culicoides spp. may also be involved in transmission (MalAvi). Therefore, the generalist $H$. minutus lineage TURDUS2 must be considered the most notable candidate for a disease spread if the distribution area of $H$. minutus and appropriate Culicoides insect vectors shift southwards.

Our findings show that parrots from Australasia and South America develop disease, while parrots native to Asia and Africa (part of the endemic range of $H$. minutus) appear to be refractory. Interestingly, blood samples taken from free-ranging ring-necked parakeets in Heidelberg, Germany, a region where both $H$. minutus lineages are present $[40,41]$, tested negative for Haemoproteus and Plasmodium parasite DNA. Ring-necked parakeets are an invasive species introduced to Germany since the 1960s and are resident in the Rhine-Neckar-region since 1974 [42]. 
Based on previous and our phylogenetic analysis of the $c y t b$ gene, the birds sampled from Heidelberg are of Asian origin [43]. As a very successful invasive species they have established multiple breeding colonies in urban areas in several European countries. In Asia, ring-necked parakeets have been reported to be infected with the Haemoproteus lineage PSIKRA01 [44]. We therefore concluded that the Asian P. krameri subspecies most likely co-evolved with a host-specific Haemoproteus lineage and is refractory to infections by $H$. minutus, probably due to their long-time overlapping distribution areas. Notably, a recent study suggests that some wild parrot species have a lower prevalence of haemoparasites than other birds due to the ingestion of secondary metabolites from their natural plant food which potentially function as antimalarials [45]. This could be another explanation why we did not detect any haemosporidian DNA in these free-living parakeets.

Haemoproteus minutus has not yet been found in molecular studies of avian species endemic to the southern hemisphere (MalAvi), although records from New Zealand from the early 20th century on the morphology of blood parasites from invasive common blackbirds and song thrushes suggest different [46]. We therefore decided to test invasive common blackbirds and song thrushes in New Zealand for Haemoproteus infection. We also sampled endemic and highly susceptible red fronted parakeets (C. novalaezandiae; Table 1) populations in overlapping island habitats. Surprisingly, we failed to detect Haemoproteus parasites in any of these birds. This result might be explained by the absence of appropriate insect vectors in New Zealand, which is currently considered free of Culicoides midges (Ministry of Primary Industries, New Zealand; https://www.mpi.govt.nz/ protection-and-response/finding-and-reporting-pests-and-diseases/surveillance-programmes/). Consequently, it is likely that Haemoproteus parasites originally introduced with European thrushes were lost due to the current absence of suitable vectors.

New Zealand has one of the highest alien bird species richness [47] and invasive species have been identified as single most prevalent threat to parrots in Australasia [48]. Invasive thrushes have been suggested to serve as important reservoir for avian Plasmodium parasites with potential spill-overs of virulent lineages in native bird populations [49]. Our data suggest, that other than for avian Plasmodium spp., which are transmitted by endemic mosquitos, a two-step introduction of (i) a suitable vector and (ii) a virulent $H$. minutus lineage would currently be needed to establish the full infection circle in thrushes and transmissions into naïve Cyanoramphus parrot populations in New Zealand. In contrast, more than 200 biting midges have been described from Australia and are potentially serving in the transmission of $>60$ Haemoproteus parasite lineages reported from Australian birds so far [50] (MalAvi). The only genetically characterized lineage of a thrush-infecting Haemoproteus spp. in Australia has been reported from the Bassian thrush (Zoothera lunulata) [51]. This thrush lineage, named ZOOLUN01 is closely related to TURDUS2 and COLL2 (Haemoproteus pallidus; Fig. 2b), which was isolated from a tooth-billed bowerbird (Scenopoeetes dentirostris) in Australia. COLL2 is infecting six bird families on four continents and as TURDUS2 can be considered a generalist Haemoproteus lineage (MalAvi). In the States of Victoria and New South Wales parrot habitats overlap with invasive European thrushes [52]. It is therefore tempting to speculate that other than for New Zealand, the introduction of $H$. minutus parasites into these thrush populations could be sufficient to cause die-offs in vulnerable parrot populations of this area.

\section{Conclusions}

We identified 18 Australasian and one South American parrot species susceptible to fatal $H$. minutus infections. To avoid mortality, these birds should be protected from bites of Culicoides spp. vectors in captivity in Europe. Multi-host (generalist) parasites such as the virulent $H$. minutus lineage TURDUS2 have to be considered suitable invaders of naïve avian ecosystems [53] by virtue of having a more diverse array of susceptible definitive hosts (i.e. biting midges) and intermediate host (bird) species [54]. Single-country endemism is one important predictor of extinction risk for Australasian parrots [48]. Further studies are needed to assess the importance of potential other risk factors for extinction events including the introduction of invasive blood parasites and the contribution of e.g. commercial animal trade, bird migration, and global climate change.

\section{Abbreviations \\ DNA: Deoxyribonucleic acid; EDTA: Ethylenediaminetetraacetic acid; PCR: Polymerase chain reaction}

\section{Acknowledgements \\ We gratefully acknowledge professional support from Vic Simpson, Robert Adlard, Mal Bryant and Mike Peirce. We thank Jana Enders and Monika Schaerig for their technical assistance.}

\section{Funding}

This research was funded by the Ministry of Economy and Competitiveness (CGL2013-41642-P/BOS), the New Zealand Department of Conservation, Massey University, Motuihe Island Trust, Tawharanui Open Sanctuary Supporters Inc., Auckland Regional Council, and the National Council of Science Mexico (CONACYT). PO is supported by the Swiss National Science Foundation (Ambizione PZOOP3_173972). 


\section{Availability of data and materials}

The dataset supporting the conclusions of this article are included within the article.

\section{Authors' contributions}

Collected samples: LO-C, DB, MS, TP, CS, MB, HG, HP, JE, JP-T and PO. Analysis and interpretation: $L O-C, D B, H E, M W, A G, J E, J P-T, G V$ and PO. Supervision of project: DB, MW, JP-T and PO. Grant funding: JP-T, LO-C and PO. Wrote the manuscript: LO-C and PO with input from all authors. All authors read and approved the final manuscript.

\section{Ethics approval and consent to participate}

The study was carried out under permission of the regional council Karlsruhe, Germany, and the New Zealand Department of Conservation (AK15300-RES, AK-20666-FAU and AK-22857-FAU), respectively.

\section{Consent for publication}

Not applicable.

\section{Competing interests}

The authors declare that they have no competing interests.

\section{Publisher's Note}

Springer Nature remains neutral with regard to jurisdictional claims in published maps and institutional affiliations.

\begin{abstract}
Author details
${ }^{1}$ Massey University, Institute of Natural and Mathematical Sciences, Massey University, Private Bag 102904, North Shore Mail Centre, Auckland 0745, New Zealand. ${ }^{2}$ International Zoo Veterinary Group, Station House, Parkwood Street, Keighley BD21 4NQ, UK. ${ }^{3}$ University of Nottingham, School of Veterinary Medicine and Science, Sutton Bonington Campus, Sutton Bonington, Leicestershire LE12 5RD, UK. ${ }^{4}$ Ayr Disease Surveillance Centre, Auchincruive, Ayr KA6 5AE, UK. ${ }^{5}$ Berlin-Brandenburg State Laboratory, Gerhard-Neumann-Str. 2, 15236 Frankfurt (Oder), Germany. ${ }^{6}$ Heidelberg University, Institute of Pharmacy and Molecular Biotechnology, Im Neuenheimer Feld 364, 69120 Heidelberg, Germany. ${ }^{7}$ Gerlach Laboratory, Grosshessloher Strasse 23, 81479 Munich, Germany. ${ }^{8}$ Pendl Laboratory, Untere Roostmatt 7, 6300 Zug, Switzerland. ${ }^{9}$ Freie Universität Berlin, Institute of Veterinary Pathology, Robert-von-Ostertag-Str. 15, 14163 Berlin, Germany. ${ }^{10}$ Zoological Society of London, Institute of Zoology, Regent's Park, London NW1 4RY, UK. "'Departamento de Biodiversidad, Ecología y Evolución, Facultad de Biología (Planta 9), Complutense University of Madrid, C/ José Antonio Novais, 2. Ciudad Universitaria, 28040 Madrid, Spain. ${ }^{12}$ Institute of Ecology, Nature Research Centre, Akademijos str. 2, 08412 Vilnius, Lithuania. ${ }^{13}$ University of Bern, Institute of Animal Pathology, Länggassstrasse 122, 3063 Bern, Switzerland.
\end{abstract}

Received: 7 September 2018 Accepted: 4 December 2018 Published online: 17 January 2019

\section{References}

1. Daszak P, Cunningham AA, Hyatt AD. Emerging infectious diseases of wildlife - threats to biodiversity and human health. Science. 2000;287:443-9.

2. Frick WF, Puechmaille SJ, Hoyt JR, Nickel BA, Langwig KE, Foster JT, et al. Disease alters macroecological patterns of North American bats. Glob Ecol Biogeogr. 2015;24:741-9.

3. Martel A, Blooi M, Adriaensen C, Rooij PV, Beukema W, Fisher MC, et al. Recent introduction of a chytrid fungus endangers Western Palearctic salamanders. Science. 2014;346:630-1.

4. Pounds JA, Bustamante MR, Coloma LA, Consuegra JA, Fogden MPL, Foster $\mathrm{PN}$, et al. Widespread amphibian extinctions from epidemic disease driven by global warming. Nature. 2006;439:161-7.

5. Tompkins DM, Carver S, Jones ME, Krkosek M, Skerratt LF. Emerging infectious diseases of wildlife: a critical perspective. Trends Parasitol. 2015;31:149-59.

6. Northover AS, Lymbery AJ, Wayne AF, Godfrey SS, Thompson RCA. The hidden consequences of altering host-parasite relationships during fauna translocations. Biol Conserv. 2018;220:140-8.

7. Atkinson CT. Avian Malaria. In: Atkinson CT, Thomas NJ, Hunter BD, editors. Parasitic Diseases of Wild Birds. Ames: Wiley-Blackwell; 2008. p. 35-53.
8. LaPointe DA, Goff ML, Atkinson CT. Thermal constraints to the sporogonic development and altitudinal distribution of avian malaria Plasmodium relictum in Hawai'i. J Parasitol. 2010;96:318-24.

9. van Riper C III, van Riper SG, Goff ML, Laird M. The epizootiology and ecological significance of malaria in Hawaiian land birds. Ecol Monogr. 1986; 56:327.

10. Valkiūnas $G$, Ilgūnas $M$, Bukauskaitė $D$, Fragner $K$, Weissenböck $H$, Atkinson $C T$, et al. Characterization of Plasmodium relictum, a cosmopolitan agent of avian malaria. Malar J. 2018;17:184.

11. Atkinson CT, Dusek RJ, Woods KL, Iko WM. Pathogenicity of avian malaria in experimentally-infected Hawaii Amakihi. J Wild Dis. 2000;36:197-204.

12. Palinauskas V, Žiegyte R, lezhova TA, Ilgūnas M, Bernotienè R, Valkiūnas $G$. Description, molecular characterisation, diagnostics and life cycle of Plasmodium elongatum (lineage pERIRUB01), the virulent avian malaria parasite. Int J Parasitol. 2016;46:697-707.

13. Dinhopl N, Nedorost N, Mostegl MM, Weissenbacher-Lang C, Weissenböck $\mathrm{H}$. In situ hybridization and sequence analysis reveal an association of Plasmodium spp. with mortalities in wild passerine birds in Austria. Parasitol Res. 2015;114:1455-62.

14. Valkiunas $\mathrm{G}$, lezhova TA. Exo-erythrocytic development of avian malaria and related haemosporidian parasites. Malar J. 2017;16:101.

15. Olias $P$, Wegelin M, Zenker W, Freter S, Gruber AD, Klopfleisch R. Avian malaria deaths in parrots, Europe. Emerg Infect Dis. 2011;17:950-2.

16. Bennett GF, Peirce MA, Ashford RW. Avian Haematozoa: mortality and pathogenicity. J Nat Hist. 1993;27:993-1001.

17. Žiegytė R, Markovets MY, Bernotienè R, Mukhin A, lezhova TA, Valkiūnas G, et al. The widespread biting midge Culicoides impunctatus

(Ceratopogonidae) is susceptible to infection with numerous Haemoproteus (Haemoproteidae) species. Parasit Vectors. 2017;10:397.

18. Donovan TA, Schrenzel M, Tucker TA, Pessier AP, Stalis IH. Hepatic hemorrhage, hemocoelom, and sudden death due to Haemoproteus infection in passerine birds: eleven cases. J Vet Diagn Invest. 2008;20:304-13.

19. Olah G, Butchart SHM, Symes A, Guzmán IM, Cunningham R, Brightsmith DJ, et al. Ecological and socio-economic factors affecting extinction risk in parrots. Biodivers Conserv. 2016;25:205-23.

20. IUCN: The IUCN red list of threatened species. Version 2018-1. <http://www. iucnredlist.org >. Accessed on 10 Aug 2018.

21. Graham-Smith G. A cystic disease of the heart, gizzard and muscles of young grass parakeets (Psittacus undulatus) due to a protozoan parasite. J Hygiene. 1907;7:552-7.

22. Ortiz-Catedral L, Ismar SMH, Baird K, Brunton DH, Hauber ME. Recolonization of Raoul Island by Kermadec red-crowned parakeets Cyanoramphus novaezelandiae cyanurus after eradication of invasive predators, Kermadec Islands archipelago, New Zealand. Conserv Evid. 2009;6:26-30.

23. Veitch CR, Gaskin C, Baird K, Ismar SMH. Changes in bird numbers on Raoul Island, Kermadec Islands, New Zealand, following the eradication of goats, rats, and cats. In: Veitch CR, Clout MN, Towns DR, editors. Island Invasives: Eradication and Management. Gland: IUCN; 2004. p. 372-6.

24. Hellgren $\mathrm{O}$, Waldenström J, Bensch S. A new PCR assay for simultaneous studies of Leucocytozoon, Plasmodium, and Haemoproteus from avian blood. J Parasitol. 2004;90:797-802.

25. Kocher TD, Thomas WK, Meyer A, Edwards SV, Paabo S, Villablanca FX, et al. Dynamics of mitochondrial DNA evolution in animals: amplification and sequencing with conserved primers. Proc Natl Acad Sci USA. 1989;86:6196-200.

26. Wright TF, Schirtzinger EE, Matsumoto T, Eberhard JR, Graves GR, Sanchez JJ, et al. A multilocus molecular phylogeny of the parrots (Psittaciformes): support for a Gondwanan origin during the cretaceous. Mol Biol Evol. 2008; 25:2141-56

27. Bennett GF, Peirce MA. Haemoproteus psittaci n. sp. (Haemoproteidae) from the African grey parrot Psittacus erithacus L. Syst Parasitol. 1992;23:21-4

28. Bennett GF, Peirce MA. Avian Haemoproteidae. 21. The haemoproteids of the parrot family Psittacidae. Can J Zool. 1986;64:771-3.

29. Valkiūnas G, Pendl H, Olias P. New Haemoproteus parasite of parrots, with remarks on the virulence of haemoproteids in naive avian hosts. Acta Trop. 2017;176:256-62.

30. Palinauskas V, lezhova TA, Krizanauskiene A, Markovets MY, Bensch S, Valkiunas G. Molecular characterization and distribution of Haemoproteus minutus (Haemosporida, Haemoproteidae): a pathogenic avian parasite. Parasitol Int. 2013;62:358-63. 
31. Bennett GF, Whiteway M, Woodworth-Lynas C. Host-parasite catalogue of the avian haematozoa. Mem Univ of Nfld Occ Pap Biol. 1982;5:1-243.

32. Valkiūnas G. Avian Malaria Parasites and Other Haemosporidia. Boca Raton: CRC Press; 2005

33. Maqsood M. Haemoproteus handai (sp. nov.) occuring in Indian parakeet (Psittacula cyanocephala). Ind Vet J. 1943;20:109-11.

34. Miltgen F, Landau I, Ratanaworabhan N, Yenbutra S. Parahemoproteus desseri n. sp.; gametogonie et schizogonie chez l'hôte naturel: Psittacula roseata de Thailande et sporogonie expérimentale chez Culicoides nubeculosus. Ann Parasitol Hum Comp. 1981;56:123-30.

35. Tarello W. Fatal Haemoproteus psittaci infection in an African grey parrot. Vet Rec. 2005;157:32

36. Bukauskaitè D, lezhova TA, Ilgūnas M, Valkiūnas G. High susceptibility of the laboratory-reared biting midges Culicoides nubeculosus to Haemoproteus infections, with review on Culicoides species that transmit avian haemoproteids. Parasitology. 2018:1-9. https://doi.org/10.1017/ S0031182018001373

37. Jenkins CN, Pimm SL, Joppa LN. Global patterns of terrestrial vertebrate diversity and conservation. Proc Natl Acad Sci USA. 2013;110:E2602-E10.

38. Moens MAJ, Pérez-Tris J. Discovering potential sources of emerging pathogens: South America is a reservoir of generalist avian blood parasites. Int J Parasitol. 2016;46:41-9.

39. Ewen JG, Bensch S, Blackburn TM, Bonneaud C, Brown R, Cassey P, et al. Establishment of exotic parasites: the origins and characteristics of an avian malaria community in an isolated island avifauna. Ecol Lett. 2012:15:1112-9.

40. Santiago-Alarcon D, MacGregor-Fors I, Kühnert K, Segelbacher G, Schaefer HM. Avian haemosporidian parasites in an urban forest and their relationship to bird size and abundance. Urban Ecosystems. 2016;19:331-46.

41. Santiago-Alarcon D, Mettler R, Segelbacher G, Schaefer HM. Haemosporidian parasitism in the blackcap Sylvia atricapilla in relation to spring arrival and body condition. J Avian Biol. 2013:44:521-30.

42. Braun M. Population development of the Ring-necked Parakeet Psittacula krameri in the Rhine-Neckar Region (Germany: Baden-Württemberg, Rhineland-Palatinate, Hesse), 1962-2008, in the context of its distribution in Europe. Vogelwelt. 2009:130:77-89.

43. Gros AL, Samadi S, Zuccon D, Cornette R, Braun MP, Senar JC, et al. Rapid morphological changes, admixture and invasive success in populations of ring-necked parakeets (Psittacula krameri) established in Europe. Biol Invasions. 2016;18:1581-98.

44. Ishtiaq F, Gering E, Rappole JH, Rahmani AR, Jhala YV, Dove CJ, et al Prevalence and diversity of avian hematozoan parasites in Asia: a regional survey. J Wildl Dis. 2007:43:382-98.

45. Masello JF, Martínez J, Calderón L, Wink M, Quillfeldt P, Sanz V, et al. Can the intake of antiparasitic secondary metabolites explain the low prevalence of hemoparasites among wild Psittaciformes? Parasit Vectors. 2018;11:357.

46. Laird M. Some blood parasites of New Zealand birds. Zool Pub Victoria Univ Coll. 1950;5:1-20.

47. Dyer EE, Cassey P, Redding DW, Collen B, Franks V, Gaston KJ, et al. The global distribution and drivers of alien bird species richness. PLoS Biol. 2017; 15:e2000942.

48. Olah G, Theuerkauf J, Legault A, Gula R, Stein J, Butchart S, et al. Parrots of Oceania - a comparative study of extinction risk. Emu. 2018;118:94-112.

49. Niebuhr CN, Poulin R, Tompkins DM. Is avian malaria playing a role in native bird declines in New Zealand? Testing hypotheses along an elevational gradient. PLoS One. 2016;11:e0165918.

50. Borkent A, Wirth WW. World species of biting midges (Diptera, Ceratopogonidae). Bulletin AMNH. 1997;233:1-257.

51. Beadell JS, Gering E, Austin J, Dumbacher JP, Peirce MA, Pratt TK, et al Prevalence and differential host-specificity of two avian blood parasite genera in the Australo-Papuan region. Mol Ecol. 2004;13:3829-44.

52. Clement P, Hathway R. Thrushes. London: A \& C Black; 2010.

53. Woolhouse ME, Taylor LH, Haydon DT. Population biology of multihost pathogens. Science. 2001;292:1109-12.

54. Rideout BA, Sainsbury AW, Hudson PJ. Which parasites should we be most concerned about in wildlife translocations? EcoHealth. 2017;14(Suppl. 1):42-6.

55. Frank W, Kaiser L. Infektionen mit Parasiten der Gattung Leucocytozoon (Protozoa, Sporozoa) bei Nachzuchten australischer Sittiche (Aves, Psittaciformes). Parasitol Res. 1967;28:370-82.

56. Takla M, Thiel W, Ullrich L. Leucocytozoon infection in parakeets. Tierarztl Prax. 1981;9:203-9.
57. Spillmann SK, Ehrsam HR, Ossent P. Leucocytozoon infections in parakeets. Schweiz Arch Tierheilkd. 1987;129:21-9.

58. Fowler N, Forbes G. Aberrant Leucocytozoon infection in parakeets. Vet Rec. 1972:91:345-7.

59. Smith G. Aberrant Leucocytozoon infection in parakeets. Vet Rec. 1972;91:106

60. Walker D, Garnham P. Aberrant Leucocytozoon infection in parakeets. Vet Rec. 1972;91:70-2

\section{Ready to submit your research? Choose BMC and benefit from:}

- fast, convenient online submission

- thorough peer review by experienced researchers in your field

- rapid publication on acceptance

- support for research data, including large and complex data types

- gold Open Access which fosters wider collaboration and increased citations

- maximum visibility for your research: over $100 \mathrm{M}$ website views per year

At BMC, research is always in progress.

Learn more biomedcentral.com/submissions 